\title{
Justification Effectiveness of Systemic Treatment of Breast Cancer Depending On Body Mass Index1se "Dnipropetrovsk Medical Academy of Health Ministry of Ukraine"
}

\author{
Hojouj Mohammad IM ${ }^{1 *}$, Chabanova $\mathrm{K}^{2}$, Bondarenko $\mathrm{IN}^{2}$, Viktor Zavizion ${ }^{1}$, Maltsova $\mathrm{L}^{2}$ and Tereshinko $\mathrm{P}^{2}$ \\ ${ }^{1}$ Department of oncology and medical radiology, Ukraine \\ ${ }^{2}$ Municipal Institution "Dnipropetrovsk City Multi-field Clinical Hospital, Ukraine
}

Submission: April 11, 2017; Published: Jun 02, 2017

*Corresponding author: Hojouj Mohammad IM, Department of oncology and medical radiology, Volodymyr Vernadskii str, 9 Dnipro, 49044, Ukraine, Email: Hojouj@yahoo.com

Keywords: Body mass index; Breast cancer; Obesity; Overall survival

\section{Background}

The incidence of breast cancer in the world in general and in Ukraine in particular is growing. In 2015, in Ukraine the incidence reached 70.0 per 100 thousand female populations. According to the Ministry of Health in Ukraine $26 \%$ of the female population for 2015 was overweight or obese. Obesity- a chronic metabolic character, which is the result of the interaction of the endogenous factors, environmental conditions and lifestyle. Endogenous factors could be considered a violation of the genetic and hormonal balance. The external conditions include irregular rhythm nutrition, use of substandard products. By disorders include sedentary lifestyle lifestyles.

Obesity is the first risk factor for metabolic syndrome, diabetes type II, cardiovascular disease and some forms of cancer, including breast cancer.

Since overweight is a risk factor for breast cancer, there is reason to believe that among patients with breast cancer the percentage of obese women is higher than in the population. The risk of breast cancer in postmenopausal women by $30 \%$ more than in premenopausal, women with obesity-50\%. Furthermore it was proven that obesity is associated with poor prognosis in patients with breast cancer, regardless of menopausal status [1].

The leading role in achieving long-term results of treatment with systemic methods, such as chemotherapy or hormone therapy. The purpose of systemic therapy is the eradication of micrometastases in the case of radical surgical treatment or reduction of tumor load in case of treatment of locally advanced or metastatic cancer. The calculation of the dose of chemotherapy conducted mainly in the area of the body [2]. Thus to avoid complications associated with overdose of chemotherapy, the standard practice is to calculate the dose of $2.0 \mathrm{~m} 2$ patients whose body area more than this. Preparations hormonal action used in standard dosage for an adult without constitutional features. Along with this recent literature there is information that women are overweight effectiveness of systemic treatments may be lower than expected. Other data refute this information [3]. In view of the above, the study on the impact of body mass index on the effectiveness of systemic treatment for breast cancer is an actual scientific problem and promising area of research. Over expression of Her-2/neu in ERpositive breast cancer cells can cause tamoxifen to behave as an agonist and stimulate cell growth. Implicit in this mechanism for resistance is cross-talk activation between the ER and the epidermal growth factor receptor (EGFR/Her-2/neu) pathways [3]. Treatment with various signal transduction inhibitors has been used in combination with endocrine therapy to overcome resistance, such as gefitinib, which targets the internal tyrosine kinase domain of EGFR, and trastuzumab, which blocks the external domain of Her-2/neu [4].

Recently, complementary and alternative medicine (CAM) is widely accepted among patients with breast cancer, which may provide several beneficial effects including reduction of therapyassociated toxicity, improvement of cancer-related symptoms, 
fostering of the immune system, and even direct anticancer effects [5]. Carnitine is a trimethylated amino acid, naturally synthesized in the liver, brain and kidney from protein-bound lysine and methionine. Several factors such as sex hormones and glucagon may impact on carnitine distribution and level in tissues [6]. L-carnitine plays an important role in cell energy metabolism through mediating the transport of long chain fatty acids across the inner mitochondrial membrane. Carnitine has a modulating effect on the function of acetylcholine excitatory neurotransmitter, glutamate excitatory amino acid, insulin growth factor-1 (IGF-1) and nitric oxide (NO). L-carnitine may have a dual protective effect by enhancing the energy dynamics of the cell and inhibiting cell membrane hyperexcitability [5], which make it an ideal nutrient for cancer prevention and treatment [7-10]. ex hormones, especially estrogens, have been implemented in the development of breast cancer. Breast cancer risk increases after menopause, where aromatization of androgens to estrogens in adipose tissue is the most important source of estrogen in blood and peripheral tissues [11]. Weight increase and obesity subsequent to menopause have been identified as the most important risk and negative prognostic factors for breast cancer in postmenopausal women. Obesity results in increased circulating levels of insulin and insulinlike growth factor, which by acting as mitogens for epithelial breast cells, stimulate their growth and neoplastic degeneration. Mechanisms may combine to explain the association which links together menopause, the subsequent body weight increase, and hormone-dependent breast cancer [12]. Body mass index of letrazol-treated breast cancer patients included in the present study was positively correlated with estrogen level (E2) which is consistent [11], who showed that the increased breast cancer risk seen in postmenopausal women with adiposity might be related to elevated sex hormone level.

The aim of this retrospective study the effect of body mass index on the efficiency of treatment of breast cancer, improve treatment outcomes for breast cancer by individualization of treatment measures taking into account the characteristics of the metabolism of the patient.

\section{Materials and Methods}

The study included 754 patients with breast cancer between the ages of 30 and $77(57,6 \pm 1)$ years of age who were treated according to our clinic, department of oncology and medical radiology . Dnipropetrovsk medical academy at Municipal Institution "Dnipropetrovsk City Multi-field Clinical Hospital \#4", Dnepropetrovsk state medical academyfrom 2005-2016. All patients were evaluated according to the following data: stage of the disease, age and BMI at the time of diagnosis, the size, histological type and metastases. IHC type ,MRI methods,Bioelectrical impedance analysis, Ultrasounds analysis.

Tumor size was evaluated after measuring its maximal diameter and distributed in accordance with the International
TNM-classification (7th edition, 2009). The histological type and degree of differentiation of the tumor was evaluated respectively by the National Standards of diagnostics and treatment of malignant neoplasms, reflecting the recommendations of leading international organizations. BMI is calculated by the formula: $\mathrm{I}=\mathrm{m} \times \mathrm{h} 2$, where $\mathrm{m}$ - body weight $(\mathrm{kg}) ; \mathrm{h}$ - height $(\mathrm{m})$. According to these calculations the patients were divided in accordance with the WHO criteria into the following groups: those with a BMI $<25 \mathrm{~kg} / \mathrm{m} 2$ - normal or underweight; from 25 to $29.9 \mathrm{~kg} / \mathrm{m} 2$ - overweight; $>30 \mathrm{~kg} / \mathrm{m} 2$ - obese. The material for the histopathological study was obtained during surgery. We examined the relative risk of relapse and death with regard to the BMI categories adjusting for eight factors known to be predictors of disease-free survival (DFS) and overall survival (OS): menopausal status, nodal status tumor size, vessel invasion, estrogen receptor (ER) status, progesterone receptor status, tumor grade and treatment regimens ECOG.

By analyzing archival material to consider the particular response to systemic treatment of breast cancer women with deficiency of body weight, normal, high and overweight. Explore options for determining the individual characteristics of lipid metabolism of patients with breast cancer and their possible use for predicting the effectiveness of treatment. To determine the lipid metabolism will be applied anthropological research methods, bioimpedansnoho measurement, CT.

\section{Results}

In this retrospective study, among 754 patients with breast cancer, $45 \%$ were identified with excess body weight, and $31 \%$ - of various obesity degrees. Patients with a BMI $<25 \mathrm{~kg} / \mathrm{m} 2$ were significantly more diagnosed with stage 2 breast cancer triple negative. BMI $>30 \mathrm{~kg} / \mathrm{m} 2,10 \%$ more often associated with metastatic RLN, which is an indirect sign of higher metastatic potentials. Patients with normal BMI had significantly longer overall survival (OS) and disease-free survival (DFS) than patients with intermediate or obese BMI in pairwise comparisons adjusted for other factors. We found a strong correlation between obesity and lymph node involvement. These observations suggest that obesity may potentiate the metastatic spread of breast tumors. Distant metastases were also found more often in obese patients in bone or visceral sites in patients $<45$ years of age at diagnosis. Patients with normal mass by IHC with triple negative cancer $45 \%$ and $20 \%$ with BRCA + and patients with obesity $55 \%$ that's with IHC luminal A.B but 2 group receive L carnitine in group with $\mathrm{L}$ carnitine by ECOG better and calendar Chemotherapy was as planed and less Adverse Advents than group Patients without support L Carnitine And less hematological complication .

\section{Conclusion}

In conclusion, this retrospective investigation of our patient demonstrates that BMI is an independent prognostic factor for OS in patients with breast cancer. We have supporting evidence that obese BMI represents a poor risk feature for outcome, 


\section{Current Trends in Clinical \& Medical Imaging}

especially in pre-/premenopausal patients, most of whom received chemotherapy without hormonal therapy. A lifestyle intervention reducing dietary fat intake, with modest influence on body weight, may improve relapse-free survival of breast cancer patients receiving conventional cancer management. Longer, ongoing nonintervention follow-up will address original protocol design plans, which requires 3 years of follow-ups after completion of recruitment. The prominent role of $\mathrm{L}$-carnitine in the present study belongs to the level of Her-2/neu, Ki67, which were significantly reduced after L-carnitine supplementation. Thus, L-CAR as add on therapy to TAM, in addition to its ability to foster the immune system and improve the patients ' fatigue and quality of life, may offer better cancer prognosis, which may be, in part, a prospective trial to overcome Chemotherapy and letrazol resistance.

\section{References}

1. Jordan VC, O'Malley BW (2007) Selective estrogen-receptor modulators and antihormonal resistance in breast cancer. J ClinOncol 25(36): 5815-5824.

2. Samaddar JS, Gaddy VT, Duplantier J, Thandavan SP, Shah M, et al. (2008) A role for macroautophagy in protection against 4-hydroxytamoxifen-induced cell death and the development of antiestrogen resistance. Mol Cancer Ther 7(9): 2977-2987.

3. Baneshi MR, Warner P, Anderson N, Edwards J, Cooke TG, et al. (2010) Tamoxifen resistance in early breast cancer: statistical modelling of tissue markers to improve risk prediction. Br J Cancer 102(10): 15031510.
4. Johnston SR (2009) Enhancing the efficacy of hormonal agents with selected targeted agents. Clin Breast Cancer 9(Suppl 1): S28-S36.

5. Porter NS, Jason LA, Boulton A, Bothne N, Coleman B (2010) Alternative medical interventions used in the treatment and management of myalgic encephalomyelitis/chronic fatigue syndrome and fibromyalgia. J Altern Complement Med 16(3): 235-249.

6. Kraemer WJ, Volek JS, Dunn-Lewis C (2008) L-carnitine supplementation: influence upon physiological function. Curr Sports Med Rep 7(4): 218-223.

7. Schubert C, Hong S, Natarajan L, Mills PJ, Dimsdale JE (2007) The association between fatigue and inflammatory marker levels in cancer patients: a quantitative review. Brain BehavImmun 21(4): 413-427.

8. Thomson DM, Krupey J, Freedman SO, Gold P (1969) The radioimmunoassay of circulating carcinoembryonic antigen of the human digestive system. Proc Natl AcadSci USA 64(1): 161-167.

9. Gion M, Plebani M, Mione R, Penzo C, Meo S, Burlina (1994) A Serum CA549 in primary breast cancer: comparison with CA15.3 and MCA. Br J Cancer 69: 721-725.

10. Passing H, Bablok (1983) A New Biometrical Procedure for Testing the Equality of Measurements from Two Different Analytical Methods. J ClinChem 21: 709-720.

11. Mahabir S1, Baer DJ, Johnson LL, Hartman TJ, Dorgan JF, et al. (2006) Usefulness of body mass index as a sufficient adiposity measurement for sex hormone Concentration associations in postmenopausal women. Cancer Epidemiol Biomarkers Prev 15(12): 2502-2507.

12. Macciò A, Madeddu C (2011) Obesity, inflammation, and postmenopausal breast cancer: therapeutic implications. Sci Wor J 11: 20202036.

13. Steiber A, Kerner J, Hoppel CL (2004) Carnitine: a nutritional, biosynthetic, and functional perspective. Mol Aspects Med 25(5-6): 455-473.

\begin{tabular}{|l|}
\hline \multicolumn{1}{|c|}{ Your next submission with Juniper Publishers } \\
will reach you the below assets \\
- Quality Editorial service \\
- Swift Peer Review \\
- Reprints availability \\
- E-prints Service \\
- Manuscript Podcast for convenient understanding \\
- Global attainment for your research \\
- Manuscript accessibility in different formats \\
( Pdf, E-pub, Full Text, Audio) \\
- Unceasing customer service \\
Track the below URL for one-step submission \\
https://juniperpublishers.com/online-submission.php \\
\hline
\end{tabular}

